\title{
The Influence of Education on Subjective Underemployment: Research on Multinational Corporations in Romania
}

\author{
Vlad I. ROSCA ${ }^{1}$ \\ Oana-Lorena ȚEPOSU
}

\begin{abstract}
The purpose of this research was to investigate what effects demographics, in general, and education, in particular (independent variables $x$ ), had on the subjective underemployment (dependent variable y) of corporate employees in Romania. A Likert Scale survey questionnaire was administered to 110 employees of multinational businesses operating in Romania during February and May 2018, asking respondents to assess to what extent they felt they were underemployed. Answers were then correlated with the demographic regressors. Perceptions of underemployment were influenced by education $(p=0.006)$, though not by other variables such as age or marital status. Results invalidate the Null Hypothesis and reveal that subjective underemployment is being manifested on the Romanian corporate labour market, touching base with previous researches in the area, showing that the higher the level education, the greater the chances of perceived underemployment to occur. At the same time, the research addresses ways to combat underemployment, such as increasing self-esteem levels, re-designing the educational system or life-long learning.
\end{abstract}

Keywords: underemployment, labour policies, recruitment, human resources management, demographic economics, job satisfaction

JEL classification: J10, J24, J28, M14, M53, M54

DOI: $10.24818 / \mathrm{RMCI} .2018 .4 .328$

\section{Introduction}

Studies have revealed that underemployment has grown to an everincreasing concern for human resources specialists since the early 2000's onwards (Kler et al., 2008; Loughrey, Hennessy, 2014), with the recent financial crisis of $2007 / 2008$ only provoking the burden farther out (Cunningham, 2016). In spite of its growing importance, the topic is still under-researched (Beukes et al., 2017; Nabi, 2003). This should not come as a surprise as far as political agendas worldwide seem to be concerned with the issue of unemployment rather than with underemployment, although specialists suggest that both are acute problems of contemporary economies (Sugiyarto, 2008).

The current paper aims to contribute towards filling the gap by conducting an analysis among corporate employees in Romania working for multinational

${ }^{1}$ Vlad I. Roșca, The Bucharest University of Economic Studies. Email: vlad_rsc@yahoo.com 
companies. As a second world country (Kwon, 2017; Swenson, 1986), Romania has got a couple of characteristics that make it prone for underemployment: market inefficiencies (Dragotă, Mitrică, 2004) and standardized labor procedures. Over the past decade, multinational businesses have increased their foreign direct investments in Romania, relocating their businesses from abroad in order to enjoy the benefits of cheaper labor and lower taxes (Bellak, Leibrecht, 2009; Carstensen, Toubal, 2004; Hanzl-Weiß, 2004; Smith et al., 2002). To reduce operational costs even further, multinationals employed highly standardized labor processes (Petrișor, Cozmiuc, 2016; Marciniak, 2012; Popirlan, 2010) that have transformed working habits into routines (Youngdahl, Ramaswamy, 2008) and which do not necessarily take the educational levels of the employees into account. The latter ones are left with the feeling that their education is useless on the job, which they often even express informally.

This research tries to find out whether this expression of irritation is really backed up by facts acknowledgeable on the labor market or if it only is a mere credence within the whole kit and caboodle of employees. For testing this aim, the paper will probe if education has indeed got any impact on the perception of underemployment and, if it does, how does it manifest.

The article starts with conceptual clarifications concerning underemployment, looking closer at its two possible forms: objective and subjective. The Methodology section presents how the market study has been carried out and how data has been collected, as well as what the research question, research objectives and research hypotheses are. The Results section presents the raw outcomes of the multiple regression among hypotheses testing, while the Analysis and interpretation section discusses the relationship between education and underemployment starting out from the results.

\section{Conceptual Clarifications}

Underemployment describes a labor situation in which the working capacity of the employee is not used at its maximum potential (Pratomo, 2015). The inadequate application of labor resources and skills (Lin et al., 2017) results in an employment background where work is being done at standards which are inferior to the abilities that an employee would be able to deliver, resulting in a diminishment of outputs (Allan et al., 2017). The precarious work conditions can be classified in two types: objective (or visible) underemployment petrains to economic policies and can be an effect of unproper work duration, compulsory part-time work or forced short-time work (Cunningham, 1996); subjective (or invisible) underemployment is also a matter of deficient productivity, occuring, though, at the perceptual level of the individual employee. Without necessarily being constrained by economical or political factors, the employee perceives a talent use gap between his potential and his actual productivity (Livingstone, 1999, 2018). In subjective undremployment, the employee acknowledges the underutilization of his capabilities (Glyde, 1977: 245) and demonstrates 
willingness to accept more work, either quantitatively or qualitatively (more challenging tasks) (Pratomo, 2015).

The use of over-qualified workers in under-specialized labor (Beukes et al., 2017) can lead to discouragement and low motivation (Slack, Jensen, 2004), which can impact both upon work-related outcomes (Kawai, Mohr, 2017), as well as upon life satisfaction (George et al., 2012). Jones-Johnson and Johnson (1992) add that subjective underemployment leads to psychosocial stress, a consequence of what Lester and McCain (2001) call 'contribution inequity': the employee being aware that he only partially contributes with his knowledge and skills to the labor requirements of the job description. As such, this translates into an instance of unjustice for the employee who recognizes that he cannot use his potential at maximum because the current job position does not permit the possibility to increase performances (Görg, Strobl, 2003).

One of the factors strongly influencing underemployment is education. Educational underemployment occurs when employees have to conclude work that does not correspond to their degrees, keeping them away from (efficiently) using their knowledge, skills or experiences gained during school or university (Cunningham, 2016). Educational underemployment (or graduate underemployment) represents a situation in which employees (usually fresh graduates) are not being offered (enough) opportunities to make use of the knowledge or skills learned back in school or university (Cassidy, Wright, 2008; Nabi, 2003). Overeducation is considered to be the mirror image (Green, Hanseke, 2016; Smith, 1986). Underemployment in general and educational underemployment in particular are specific for second world and third world countries, where the inefficience of labor markets (compared to their first world counterparts) is a serious problem that forces people into work unsuitable to their qualifications (Görg, Strobl, 2003; Sordyl, 2014).

\section{Methodology}

As a second-world country (Khanna, 2008; McMillan, 1987), Romania is exposed to the risk of underemployment (Robila, Krishnakumar, 2005). With foreign direct investments made by multinationals (relying on standardization as a means to penetrate emerging markets and reduce costs), the chances of subjective underemployment are high (Ozsomer et al., 1991). Researches have revealed employment vulnerability in the Romanian labor sector (Patache, 2014), amongst others characterized through gaps between employee knowledge capital and labor offered (Jianu, Chiș, 2012). The ongoing transition stage of the Romanian labor market creates demographic challenges for employers and employees alike: reduced fertility (Rotariu, 2006), export of labor towards Western Europe (Piperno, 2007), reduced young age workforce (Aleksandrova, Velkova, 2003) and ageing population (Georgescu, Herman, 2010) are only some of the demanding facts that drive multinational companies towards employing whatever workforce available, irrespective of education or certain other demographic aspects, only by being 
confident in the business philosophy that the more standardized the labor is, the easier it will be to teach work-related skills through on-the-job training or shadowing, thus creating a imbalance between the ideal and the actual demographic profile of an employee, which can turn into (subjective) underemployment (Alexander et al., 2017).

Starting from this problem, the research aim of this paper is to investigate the effect of demographics on subjective underemployment among corporative employees in Romania. Subsequently, the research question asks:

\section{What is the effect of demographics on subjective underemployment among corporative employees in Romania?}

The research objectives set were:

a.) Identify whether demographics had any influence on how employees perceived underemployment;

b.) If a.) was true, identify which demographic variable had more impact on perceived underemployment;

c.) Identify and discuss the role of education in perceived underemployment.

The research has been based on the following hypotheses:

HO: There is no relationship between underemployment and demographic variables: The Null Hypothesis is backed up by the fact that underemployment is a function of several conditions other than demographics alone. In this case, it is difficult to claim that there is a direct relationship between demographics and underemployment without taking into account other aspects such as social support, job search efficiency, job search intensity, cultural knowledge etc. (Guerrero, Rothstein, 2012).

In the case that the Null Hypothesis is declared untrue, the following two alternative hypotheses are developed:

H1: Subjective underemployment is manifested among employees on the Romanian labor market: Underemployment has been demonstrated to exist in Romania (Robila, 2003), yet most studies up to date have been concerned with visible underemployment (Maria, 2011; Motoi, Gheorghiță, 2017). Little to no studies have been concerned with subjective underemployment in Romania. However, given that subjective underemployment is such a global problem, it can be hypothesized that it exists in Romania as well.

H2: There is a connection between level of education and subjective underemployment: Of all factors potentially affecting the perception of underemployment, education seems to be the strongest. Previous researches have demonstrated a connection to exist between the two variables (Cunningham, 2016; 
Sikora et al., 2016). The present study starts from the prerequisite that the same connection is as well valid for the Romanian multinationals' context selected.

The data sample for this research has been drawn from an extended survey concerned with creativity at the workplace. The survey has been carried out between February and May 2018. 110 employees from multinational companies based in Romania have answered to a questionnaire, in which they had to evaluate assertions linked to their working habits based on a 1 to 4 Likert Scale (where $1=$ total disagreement, $2=$ disagreement, $3=$ agreement, $4=$ total agreement). One of the assertions that respondents had to rate was "I believe I am underemployed in my current job position". This assertion has been used for the current research as the dependent variable (y) and linked with the demographic (independent) variables (x) of the questionnaire.

A multiple regression has been carried out with Microsoft Excel. The regression function employed has been:

$$
y=f\left(x_{1}, x_{2}, x_{3}\right)
$$

where: $x_{1}=$ education, $x_{2}=$ marital status, $x_{3}=$ age

Education $\left(x_{1}\right)$ has been defined as the last degree that the respondent has graduated from (primary studies, secondary-, upper-secondary-, bachelor-, masters, Ph.D.- or postdoctoral-). The Confidence interval was set at $95 \%$, producing a Cronbach alpha level of $\alpha=0.05$.

\section{Results}

Table 1 shows the results of the ANOVA Analysis. The Significance F level of 0.046 is lower than the critical alpha level of 0.05 , thus invalidating the Null Hypothesis. There is a relationship between subjective underemployment and demographic variables.

Table 1: Results of the ANOVA Analysis

\begin{tabular}{|l|rrrrr|}
\hline & \multicolumn{1}{|c}{ ANOVA } \\
\hline & $d f$ & \multicolumn{1}{c}{ SS } & \multicolumn{1}{c|}{$M S$} & \multicolumn{1}{c|}{ S } & Significance $F$ \\
\hline Regression & 3 & 8.9266 & 2.975533 & 2.744385 & 0.046718 \\
Residual & 106 & 114.9279 & 1.084226 & & \\
Total & 109 & 123.8545 & & & \\
\hline
\end{tabular}

Source: Own computations

Nevertheless, the relationship is only weak, as demonstrated by the Multiple R value of 0.26 displayed in Table 2 .

332 Review of International Comparative Management Volume 19, Issue 4, October 2018 
Table 2: Regression Statistics

\begin{tabular}{|lr|}
\hline \multicolumn{2}{|c|}{ Regression Statistics } \\
\hline Multiple R & 0.268465 \\
R Square & 0.072073 \\
Adjusted R Square & 0.045811 \\
Standard Error & 1.041262 \\
Observations & 110 \\
\hline
\end{tabular}

Source: Own Computations

The only valid predictor variable is Education, with a P-Value lower than the critical alpha level $(0.006<\alpha=0.05)$. The other two variables are not relevant, their P-Values being higher than the alpha level $(0.86>\alpha=0.05$ for marital status, and $0.21>\alpha=0.05$ for age), as can be observed in Table 3 .

Table 3: Regression Coefficients

\begin{tabular}{|l|cccccccc|}
\hline & Coefficients & $\begin{array}{c}\text { Standard } \\
\text { Error }\end{array}$ & $t$ Stat & P-value & $\begin{array}{c}\text { Lower } \\
95 \%\end{array}$ & $\begin{array}{c}\text { Upper } \\
95 \%\end{array}$ & $\begin{array}{c}\text { Lower } \\
95.0 \%\end{array}$ & $\begin{array}{c}\text { Upper } \\
95.0 \%\end{array}$ \\
\hline Intercept & 2.737024 & 0.510042 & 5.366268 & 0.000000476 & 1.725815 & 3.748232 & 1.725815 & 3.748232 \\
EDUCATIE & -0.44167 & 0.157775 & -2.79935 & 0.00608535 & -0.75447 & -0.12886 & -0.75447 & -0.12886 \\
STARECIV & -0.01978 & 0.115923 & -0.17063 & 0.86483798 & -0.24961 & 0.210049 & -0.24961 & 0.210049 \\
VARSTA & 0.132227 & 0.105067 & 1.258503 & 0.21097458 & -0.07608 & 0.340533 & -0.07608 & 0.340533 \\
\hline \multicolumn{7}{c}{ Source: Own Computations }
\end{tabular}

\section{Analysis and Interpretation}

Research results validate the alternative hypotheses. Subjective underemployment exists on the Romanian labor market, even though its relationship towards demographics is only weak. An explanation for this would be that demographic variables are not the most relevant factors to impact upon perceived underemployment (Guerrero, Rothstein, 2012). The fact that age and marital status do not correlate with the perception of underemployment while education does might be an outcome of the different levels of control that the HR recruiters of multinational companies exert over the variables when in search of hiring employees. When recruiting, companies are properly looking at age or marital status (Armstrong-Stassen, Templer, 2005; McEvoy, Cascio, 1989). There is, though, a trend to care less about education, due to the fact that, within the knowledge and digital societies currently witnessed, knowledge tends to get outdated fast, so that multinational companies prefer to invest in delivering their own job-related training to employees, irrespective of their formal educational degrees. Xiao (2002) has found out that formal education only has an impact on the salary level at the moment of hiring, but that future, post-employment wage increases are a condition of specialized knowledge and skills acquired on the job and, according to Brown (1989), backed up by tenure - which are preponderantly guaranteed by training. Barron et al. (1999) embrace the same by claiming that, on 
the long run, the acquisition of skills through training can lead to higher wages, however, at the same time, on-the-job training allows employers to bid with reduced starting wages. Moreover, highly-educated job prospects would demand higher wages, which would contradict a certain low-cost business philosophy that has driven multinationals to Romania in search of cheaper labor (Ajorca, Belu, 2012). As such, multinationals prefer to recruit less educated or less knowleadgable prospects because they cost less and then train them internally, which is a less expensive strategy than having to pay according to educational level (Mincer, 1962).

The only demographic variable found to have an influence on underemployment was education. The identification of this connection is in line with previous studies. There is a negative correlation between education and the perception of underemployment, indicating that, the better educated an individual is, the higher the chances are that, once employed within a corporation, that person will perceive him-/herself as underemployed. In the particular case of Romania, this hiatus between individual knowledge capital and labor provided has previously been addressed by Jianu and Chiș (2012), who concluded that additional, taskspecific on-the-job training was still needed, irrespective of the levels of education employees had.

In a study conducted over 268 expats from multinational companies worldwide, Bolino and Feldman (2000) have identified that many top-managers are overqualified for the assignments received on the job, mainly as a result of their chosen education. The results of the current research show that employees of foreign corporations in Romania perceive their job quality inferior to a selfimposed standard. Feldman (1996) believes that this type of standard or selfjudgement is directly proportional to the level of education. The author states that the harsher the individual is with the own standard levels, the greater the chances of negative health and mental state conditions. Self-set standards might be of high level with Romanian employees, since education is being perceived as an investment made towards one's development, which would ideally have to ripen benefits throughout life. High own standards can lead to low self-esteem levels and depression are also identified as consequences of underemployment by Dooley et al. (1994), Friedland and Price (2003) and Prause and Dooley (1997).

Nevertheless, many studies have indicated that subjective underemployment should not automatically be attributed to the individual. AcostaBallesteros et al. (2018) have suggested that, in order to avoid perceptions of underemployment, the educational system should re-design its curricula so as to allow students to be educated with more job-similar (real-life) methods. The authors claim that education should put more emphasis on skills rather than on knowledge, especially in highly-competitive, fast-changing industries, such as scitech. Skill mismatch (Clogg, Shockey, 1984; Flisi et al, 2017; Halaby, 1994) could be thus avoided. Acosta-Ballesteros et al's findings also reveal that the feeling of underemployment is more likelier to appear with graduates of humanistic sciences, since these latter ones put more emphasis on knowledge-learning than applied

$334 \quad$ Review of International Comparative Management

Volume 19, Issue 4, October 2018 
sciences do. In a knowledge-based and information-based economy such as the one today (Dragomirescu, 2004; Drăgănescu, 2003), the turnover rate of relevant knowledge is high: knowledge gets outdated very fast by a plenitude of other knowledge that the individual is exposed to through the technological development of communication channels (e.g. the internet). With this phenomenon happening, it is often only a matter of a couple of years until fresh graduates feel that the knowledge they have learned in school or university is no longer relevant on the job. Therefore, Livingstone $(1999,2000)$ advocates for lifelong learning as method to combat or at least to delay the risk of underemployment.

A different school of scientific thought in what concerns the efforts to tackle perception of underemployment focuses on post-scholar decision-making. Bederman and Adams (1974) suggest that the feeling of underemployment should be combatted by on-the-job training or better placement of employees by recruiters, while Anstätt and Volkert (2016) urge business managers to implement Corporate Social Responsibility decisions at the wider levels of the organization in order to combat underemployment.

\section{Conclusions}

Görg and Strobl's (2003) argument that underemployment is specific for second world and third world economies is also backed up by findings of this research. The fact that subjective underemployment is demonstrated to exist amongst domestic employees working in multinational corporations should come as no wonder since both Romanian labor market and educational system have demonstrated failures even after the collapse of the communist-socialist block.

Correlating the findings of this research with the ideas defended by Xiao (2002) and by Jianu and Chiș (2012), it can be concluded that one of the reasons why subjective underemployment is being manifested among Romanian corporate employees is that their multinational employers do not necessarily care about previous education at the moment of recruiting, knowing that their standardized labor procedures will require employees (irrespective of their level or specialization of education) to follow a given set of cut-and-dried on-the-job trainings. It is highly advisable for subject matter experts (human resources specialists, law-makers, managers, economists, labor experts, politicians etc.) to take subjective underemployment more seriously into consideration. This research has demonstrated a widespread yet unproven credence within Corporate Romania: that employees feel and believe that the work they do is not suitable with their education, leading to chords of frustration and transforming corporate jobs into nuisance. Academia can contribute to tackling these feelings (which, if left unaddressed, can conduct to an erosion of the workplace harmony and to bad image and reputation for the corporate sector) through dedicated research and original findings, that should dwelve into handling the topic of perceived underemployment more seriously. 


\section{References}

Acosta-Ballesteros, J., Osorno-del Rosal, M. D. P., \& Rodríguez-Rodríguez, O. M. (2018). Underemployment and employment among young workers and the business cycle in Spain: the importance of education level and specialisation. Journal of Education and Work, 31(1), 28-46.

Ajorca, D., Belu, G.M. (2012). Investments in The Real Estate Sector. A Case Study On Central Eastern Europe. The Annals of The University Of Oradea. Economic Sciences, XXI(1), 90-95.

Aleksandrova, S., \& Velkova, A. (2003). Population ageing in the Balkan countries. Folia Medica, 45(4), 5-10.

Alexander, J., Ford, J., Raghavendra, P., \& Clark, J. (2017). Nature and extent of on-the-job training for employees with an intellectual disability: a pilot study. Research and Practice in Intellectual and Developmental Disabilities, 1-11. DOI: 10.1080/23297018.2017.1359661.

Allan, B. A., Tay, L., \& Sterling, H. M. (2017). Construction and validation of the subjective underemployment scales (SUS). Journal of Vocational Behavior, 99, 93-106.

Anstätt, K., \& Volkert, J. (2016). Corporate Social Responsibility impacts on sustainable human development. Ekonomski vjesnik/Econviews-Review of Contemporary Business, Entrepreneurship and Economic Issues, 29(1), 193210.

Armstrong-Stassen, M., \& Templer, A. (2005). Adapting training for older employees: The Canadian response to an aging workforce. Journal of Management Development, 24(1), 57-67.

Barron, J. M., Berger, M. C., \& Black, D. A. (1999). Do workers pay for on-thejob training?. Journal of Human Resources, 34(2), 235-252.

Bederman, S. H., \& Adams, J. S. (1974). Job accessibility and underemployment. Annals of the Association of American Geographers, 64(3), 378-386.

Bellak, C., \& Leibrecht, M. (2009). Do low corporate income tax rates attract FDI?-Evidence from Central-and East European countries. Applied Economics, 41(21), 2691-2703.

Beukes, R., Fransman, T., Murozvi, S., \& Yu, D. (2017). Underemployment in South Africa. Development Southern Africa, 34(1), 33-55.

Bolino, M. C., \& Feldman, D. C. (2000). The antecedents and consequences of underemployment among expatriates. Journal of Organizational Behavior, 21(8), 889-911.

Brown, J. N. (1989). Why do wages increase with tenure? On-the-job training and life-cycle wage growth observed within firms. The American Economic Review, 79(5), 971-991.

Carstensen, K., \& Toubal, F. (2004). Foreign direct investment in Central and Eastern European countries: a dynamic panel analysis. Journal of Comparative Economics, 32(1), 3-22. 
Cassidy, T., \& Wright, L. (2008). Graduate employment status and health: A longitudinal analysis of the transition from student. Social Psychology of Education, 11(2), 181-191.

Clogg, C. C., \& Shockey, J. W. (1984). Mismatch between occupation and schooling: A prevalence measure, recent trends and demographic analysis. Demography, 21(2), 235-257.

Cunningham, J. (2016). Credential disconnection: a Marxist analysis of college graduate underemployment. Critical Studies in Education, 57(2), 224-237.

Dooley, D., Catalano, R., \& Wilson, G. (1994). Depression and unemployment: panel findings from the Epidemiologic Catchment Area study. American Journal of Community Psychology, 22(6), 745-765.

Dragomirescu, H. (2004). Mihai Draganescu - „De la societatea informationala la societatea cunoasterii”. Revista Informatică Economică, nr. 8(1/29), 145.

Dragotă, V., \& Mitrică, E. (2004). Emergent capital markets' efficiency: The case of Romania. European Journal of Operational Research, 155(2), 353-360.

Drăgănescu, M. (2003). De la societatea informationala la societatea cunoasterii. Editura Tehnică, București.

Feldman, D. C. (1996). The nature, antecedents and consequences of underemployment. Journal of Management, 22(3), 385-407.

Flisi, S., Goglio, V., Meroni, E. C., Rodrigues, M., \& Vera-Toscano, E. (2017). Measuring occupational mismatch: overeducation and overskill in europeevidence from PIAAC. Social Indicators Research, 131(3), 1211-1249.

Friedland, D. S., \& Price, R. H. (2003). Underemployment: Consequences for the health and well-being of workers. American Journal of Community Psychology, 32(1-2), 33-45.

George, U., Chaze, F., Fuller-Thomson, E., \& Brennenstuhl, S. (2012). Underemployment and life satisfaction: A study of internationally trained engineers in Canada. Journal of Immigrant \& Refugee Studies, 10(4), 407-425.

Georgescu, M., \& Herman, E. (2010). Aspecte particulare ale îmbatrânirii populatiei din România postcomunista-consecinte socioeconomice. Sociologie Romaneasca, 8(4), 91-103.

Glyde, G. P. (1977). Underemployment: Definition and causes. Journal of Economic Issues, 11(2), 245-260.

Görg, H., \& Strobl, E. (2003). The incidence of visible underemployment: Evidence for Trinidad and Tobago. Journal of Development Studies, 39(3), $81-100$.

Green, F., \& Henseke, G. (2016). Should governments of OECD countries worry about graduate underemployment?. Oxford Review of Economic Policy, 32(4), 514-537.

Guerrero, L., \& Rothstein, M. G. (2012). Antecedents of underemployment: Job search of skilled immigrants in Canada. Applied Psychology, 61(2), 323-346.

Halaby, C. N. (1994). Overeducation and skill mismatch. Sociology of Education, 67(1), 47-59. 
Hanzl-Weiß, D. (2004). Enlargement and the textiles, clothing and footwear industry. The World Economy, 27(6), 923-945.

Jianu, C., \& Chiş, C. (2012). Study on the hygiene knowledge of food handlers working in small and medium-sized companies in western Romania. Food Control, 26(1), 151-156.

Jones-Johnson, G., \& Johnson, W. R. (1992). Subjective underemployment and psychosocial stress: The role of perceived social and supervisor support. The Journal of Social Psychology, 132(1), 11-21.

Kawai, N., \& Mohr, A. (2017). How does perceived underemployment influence expatriate job-related outcomes? A moderated mediation study. The International Journal of Human Resource Management, 28, 1-27.

Khanna, P. (2008). The second world: empires and influence in the new global order. Random House.

Kler, P., Potia, A. H., \& Shankar, S. (2018). Underemployment in Australia: a panel investigation. Applied Economics Letters, 25(1), 24-28.

Kwon, N. H. C. (2017). Scientific Management in Healthcare at the International Level. The PPE Review, 6(December 2017), 82-92.

Lester, B. Y., \& McCain, R. A. (2001). An equity-based redefinition of underemployment and unemployment and some measurements. Review of Social Economy, 59(2), 133-159.

Lin, B., Law, K. S., \& Zhou, J. (2017). Why is underemployment related to creativity and OCB? A task-crafting explanation of the curvilinear moderated relations. Academy of Management Journal, 60(1), 156-177.

Livingstone, D. W. (1999). Lifelong learning and underemployment in the knowledge society: A North American perspective. Comparative Education, 35(2), 163-186.

Livingstone, D. W. (2000). Researching expanded notions of learning and work and underemployment: Findings of the first Canadian survey of informal learning practices. International Review of Education, 46(6), 491-514.

Livingstone, D. W. (2018). The Education-Jobs Gap: Underemployment or Economic Democracy?. Routledge.

Loughrey, J., \& Hennessy, T. (2014). Hidden underemployment among Irish farm holders 2002-2011. Applied Economics, 46(26), 3180-3192.

Marciniak, R. (2012). The Hungarian Shared Service Market Or What Are The Drivers And The Obstacles Of Progress?. International Journal of Business and Management Studies, 4(1), 133-141.

Maria, B. A. (2011). Unemployment, a Phenomenon of Global Imbalance. The Evolution in Romania in the Last 20 Years. Ovidius University Annals, Economic Sciences Series, 11(1), 153-158.

McEvoy, G. M., \& Cascio, W. F. (1989). Cumulative evidence of the relationship between employee age and job performance. Journal of Applied Psychology, 74(1), 11-17.

McMillan, C. H. (1987). Multinationals from the second world. Springer.

$338 \quad$ Review of International Comparative Management

Volume 19, Issue 4, October 2018 
Mincer, J. (1962). On-the-job training: Costs, returns, and some implications. Journal of Political Economy, 70(5, Part 2), 50-79.

Motoi, G., \& Gheorghiţă, V. (2017). The Consequences of Economic Recession on the Quality of Life in Romania, between 2009 and 2013. Revista de Stiinte Politice, (56), 34-43.

Nabi, G. R. (2003). Graduate employment and underemployment: opportunity for skill use and career experiences amongst recent business graduates. Education+Training, 45(7), 371-382.

Ozsomer, A., Bodur, M., \& Tamer Cavusgil, S. (1991). Marketing standardisation by multinationals in an emerging market. European Journal of Marketing, 25(12), 50-64.

Patache, L. (2014). Adverse impact of crisis on employment vulnerability in Romania. Economics, Management and Financial Markets, 9(4), 480-485.

Petrişor, I., \& Cozmiuc, D. (2016). Specific Business Models for Romanian Companies-Shared Services. Procedia-Social and Behavioral Sciences, 221, $151-158$.

Piperno, F. (2007). From care drain to care gain: Migration in Romania and Ukraine and the rise of transnational welfare. Development, 50(4), 63-68.

Popirlan, C. I. (2010). Knowledge processing in contact centers using a multi-agent architecture. WSEAS Transactions on Computers, 9(11), 1318-1327.

Pratomo, D. S. (2015). The analysis of underemployment in Indonesia: determinants and its implication. Procedia-Social and Behavioral Sciences, $211,528-532$.

Prause, J., \& Dooley, D. (1997). Effect of underemployment on school-leavers' self-esteem. Journal of Adolescence, 20(3), 243-260.

Robila, M. (2003). Romanian families. In J. Ponzetti (Ed.), International Encyclopedia of Marriage and Family (2nd ed., Vol. 3, 1370-1373). Macmillan, New York/NY.

Robila, M., \& Krishnakumar, A. (2005). Effects of economic pressure on marital conflict in Romania. Journal of Family Psychology, 19(2), 246-251.

Rotariu, T. (2006). Romania and the second demographic transition: The traditional value system and low fertility rates. International Journal of Sociology, 36(1), 10-27.

Sikora, D. M., Thompson, K. W., Russell, Z. A., \& Ferris, G. R. (2016). Reimagining overqualified human resources to promote organizational effectiveness and competitive advantage. Journal of Organizational Effectiveness: People and Performance, 3(1), 23-42.

Slack, T., \& Jensen, L. (2004). Employment adequacy in extractive industries: An analysis of underemployment, 1974-1998. Society and Natural Resources, $17(2), 129-146$.

Smith, H. L. (1986). Overeducation and underemployment: An agnostic review. Sociology of Education, 59(2), 85-99. 
Smith, A., Rainnie, A., Dunford, M., Hardy, J., Hudson, R., \& Sadler, D. (2002). Networks of value, commodities and regions: reworking divisions of labour in macro-regional economies. Progress in Human Geography, 26(1), 41-63.

Sordyl, M. (2014). "Przyzwoite zatrudnienie" jako narzędzie antykryzysowe i szansa na zrównoważony rozwój. Studia I Prace WNEIZ US, 35(2), 209-237.

Sugiyarto, G. (2008). Measuring underemployment: does the cut-off point really matter?. Journal of the Asia Pacific Economy, 13(4), 481-517.

Swenson, R. G. (1986). Incorporating International Business: Suggestions for College Instruction. Journal of Geography, 85(3), 106-115.

Xiao, J. (2002). Determinants of salary growth in Shenzhen, China: An analysis of formal education, on-the-job training, and adult education with a three-level model. Economics of Education Review, 21(6), 557-577.

Youngdahl, W., \& Ramaswamy, K. (2008). Offshoring knowledge and service work: A conceptual model and research agenda. Journal of Operations Management, 26(2), 212-221. 